\title{
Body satisfaction versus anthropometric and lifestyle characteristics in secondary school youth in a three-year study
}

\author{
EWA RĘBACZ-MARON, ${ }^{1}$ PATRYK LISIECKI ${ }^{2}$ \\ ${ }^{1}$ University of Szczecin, Department of Vertebrate Zoology and Anthropology, Institute for Research on Biodiversity, Faculty \\ of Biology, ul. Wąska 13, 71-415 Szczecin, Poland, e-mail: rebae@univ.szczecin.pl \\ ${ }^{2}$ Student of biology at the University of Szczecin
}

Keywords

Abstract body satisfaction, anthropometry, high-school youth, lifestyle, eating habits, eating behaviours

Background. The current trend for a slim body has spread to all age groups and social strata. It is necessary to monitor health- and eating-related behaviours among young people to counteract bad eating habits.

Aim. To examine body satisfaction taking into account anthropometrics and physical activity data in high-school youth over the course of a three-year study.

Material \& Methods. Anthropological examinations on the same high-school students were conducted in: 2014, 2015, 2016 - always in September. The parameters measured included: body weight, body height (B-v), waist and hip circumference. Somatic indices were calculated: BMI, WHR, Rohrer's index. The study also included a questionnaire with questions about the number of hours of physical activity per week, the length of time in training in a given sports discipline, self-assessment of body satisfaction and eating habits.

Results. For both girls and boys the intensity of physical exercise declined year by year. The potential reason may be that the young people got to know one another after the first year and did not feel compelled to work on their body (to appear more attractive). As many as 56\% of girls were not satisfied with their body in first grade and $71 \%$ of boys. In the two subsequent years, dissatisfaction rates dropped for both sexes.

Conclusions. There is a need for health-promoting programmes so that young people can learn about the principles of nutrition and not experiment with excessive dieting.

\section{Zadowolenie z własnej sylwetki wobec charakterystyki antropometrycznej i trybu życia u młodzieży licealnej w ciągu trzech lat badań}

Słowa kluczowe

zadowolenie z własnej sylwetki, antropometria, młodzież licealna, tryb życia, nawyki żywieniowe, zachowania żywieniowe

Streszczenie Tło. Współczesna moda na szczupłą sylwetkę przenika do wszystkich grup społecznych w każdym wieku. Monitorowanie zachowań zdrowotnych i żywieniowych wśród młodzieży jest niezbędne, aby przeciwdziałać złym nawykom żywieniowym.

Cel. Zbadanie zadowolenia z własnej sylwetki przy uwzględnieniu antropometrii i aktywności ruchowej u młodzieży licealnej w ciągu trzech lat badań. 
Materiał \& Metoda. Badania antropologiczne u tej samej młodzieży licealnej zostały wykonane w 2014, 2015, 2016 roku - zawsze we wrześniu. Zmierzono: masę ciała, wysokość ciała (B-v), obwód pasa i bioder. Wyliczono wskaźniki somatyczne: BMI, WHR, wskaźnik Rohrera. Pytania ankietowe dotyczyły liczby godzin aktywności fizycznej w tygodniu, jak długo trenuje uczeń podaną dyscyplinę sportową, ocena zadowolenia z własnej sylwetki, wywiad dotyczący nawyków żywieniowych.

Wyniki. U dziewcząt i chłopców intensywność ćwiczeń fizycznych z roku na rok spadała. Być może dlatego, że młodzież się poznała po pierwszym roku i już nie chciała pracować nad sylwetką (dla większej atrakcyjności). Aż 56\% dziewcząt nie było zadowolonych w I klasie ze swojej sylwetki i 71\% chłopców. W dwóch kolejnych latach nauki odsetek niezadowolonych obniżył się u obu płci.

Podsumowanie. Konieczne jest wdrażanie programów prozdrowotnych, aby młodzi ludzie poznali zasady żywieniowe i nie eksperymentowali z przesadnym kontrolowaniem masy ciała.

\section{Introduction}

In the contemporary world appearance plays a very significant role in people's lives. Body shape is of particular importance to young people, who are prone to body insecurities and because of that liable to cause considerable damage to themselves and their health. Young people tend to pursue the ideal look, often inspired by the mass media (Kakeshita, Almeida, 2006). For instance, it was demonstrated that young women with poor eating habits are seven times more likely to develop eating disorders than women who observe the rules of healthy nutrition (Patton et al., 1999). Eating disorders form a group of psychosomatic disorders, characterised by strong deviations from healthy eating patterns. Patients suffer mostly from symptoms related to distorted body image, which makes them see themselves as having excess weight even though their actual weight is normal or even extremely low (Myszkowska-Ryciak et al., 2015).

However, teenagers are not always aware of the fact that their appearance-related problems are rooted in bad nutrition and unhealthy lifestyles. Often, in spite of knowing the theory on good nutrition, young people do not adhere to the principles of healthy eating, and as a result perpetuate the bad eating habits developed in childhood. Physical inactivity and poor eating habits persistent from childhood have a serious impact on health in later life, including such problems as irondeficiency anaemia, obesity, eating disorders (anorexia nervosa, bulimia nervosa) (Woynarowska, 2003). They often contribute to the development in adult life of many chronic metabolic diseases "of civilisation", like e.g. cardiovascular disease caused by excessive consumption of animal fats (US Public Health Service, 1988) or insufficient calcium levels in bones leading to osteoporosis in later life, especially in women (Sandler at al., 1985). On the other hand, low body weight associated with protein-energy malnutrition as well as deficiencies of minerals and vitamins may disrupt the processes of physical and sexual growth in adolescence and later ontogenetic stages leading to problems with fertility, and in extreme cases even to cachexia (Szponar, Respondek, 2000).

Many of those young people who are unhappy about their body shape fail to take into account the fact that puberty brings dramatic changes in the body. During this period, the body may for some time look disproportionate, awkward, while skin and hair may be far from perfect. In a large percentage of dissatisfied teenagers, their body weight self-assessment differs from BMI-based standards of normal nutrition (Wojtyła-Buciora, Marcinkowski, 2010), and they often regard themselves as too slim or too fat. Still, discrepancies between reality and self-perception tend to be more common among people who are actually overweight or obese and who, having lived since childhood among people with excess weight, consider it to be the norm (Maximowa et al., 2008). To bridge this gap between real and self-perceived body weight, awareness campaigns should be 
organised for young people on healthy lifestyles, correct assessment and healthy self-perception of own appearance. Interestingly, children/teenagers are often very similar, also in terms of weight, to their parents as they were at the same calendar age (Sorensen et al., 1983), which proves that body shape predisposition is to a large degree genetically determined. On the other hand, environmental factors and health-oriented behaviours play a significant role in the prevention of lifestyle diseases (diseases of civilisation), so it would be unwise to dismiss them and attribute extra kilograms solely to genetic factors.

In the case of bulimia and anorexia, unrealistic perceptions of a fat, stocky body give rise to tension and strong emotions, causing stress (Schneider et al., 2009). Prolonged stress may contribute to anxiety disorders, depression, neuroses, and under special circumstances may lead to personality disorders. Long-term studies show that depressed moods and depression are predisposing factors for actual weight gain - overweight and obesity - during puberty and in later life (Tanofsky-Kraff et al., 2006).

Therefore, it seems necessary to monitor health- and eating-oriented behaviours among youth and to develop health-promoting programmes to counteract unhealthy practices related to body weight management (Wojtyła-Buciora, Marcinkowski, 2010).

\section{Materials and methods}

Young people were examined in three consecutive years between 2014 and 2016, always at the beginning of the school year. Examinations included one class from high school no 7 (Liceum Ogólnokształcace $n r$ VII) in Szczecin, majoring in biology with elements of forensic science. The collected material yielded anthropological information on students. The analysis covers a group of $n=34$ individuals born in 1998. In the final year of the study, 2016, the students reached the age of 18. Examinations were non-invasive, and the form master, school principal and students' parents had given their consent to the anthropological research. Participation in the study was voluntary, and there were no consequences for refusing to take part. The students were measured for: body height $(\mathrm{B}-\mathrm{v})[\mathrm{cm}]$, waist circumference and hip circumference $[\mathrm{cm}]$ as well as body weight $[\mathrm{kg}]$. To examine body build, the following somatic indices were calculated:

1. Body Mass Index BMI = body weight $[\mathrm{kg}] /(\mathrm{B}-\mathrm{v})[\mathrm{m}]^{2}$.

Results were interpreted based on WHO classification, where BMI $\leq 18.49$ corresponds to underweight; BMI 18.50-24.99 normal (healthy weight) range; and BMI 25.00-29.99 overweight; BMI 30.00-34.99 obesity $1^{\circ}$; BMI 35.00-39.99 obesity $2^{\circ}$; BMI $\geq 40$ obesity $3^{\circ}$ (Physical Status 1995).

2. WHR $=$ Waist-to-Hip Ratio $=$ waist circumference $[\mathrm{cm}] /$ hip circumference $[\mathrm{cm}]$, which describes the distribution of subcutaneous adipose tissue, and identifies the android and gynoid type of fat distribution.

Results were interpreted based on the following classification: WHR $\geq 0.8$ in women indicates visceral fat accumulation, i.e. the android body type (the "apple"), whereas WHR $<0.8$ is characteristic of the gynoid body type (the "pear"). Among men, the android type corresponds to WHR $\leq 1.0$ and gynoid fat distribution - WHR $>1.0$ (Drozdowski, 1998).

3. Rohrer's Index $=$ body weight $[\mathrm{g}] /(\mathrm{B}-\mathrm{v})^{3}[\mathrm{~cm}]$, which indicates the degree of leanness or corpulence.

Rohrer's index of $\leq 1.36$ indicates a lean figure for 16-year-old girls, the value of $\leq 1.39$ indicates a lean figure for 17-year-old girls, and $\leq 1.41$ indicates a lean figure for 18 -year-old girls. Values above the thresholds listed above indicate a corpulent figure for each of the 
respective age categories. Likewise, for boys Rohrer's index scores of $\leq 1.23, \leq 1.25$ and $\leq 1.27$ indicate a lean figure for: 16-year-old, 17-year-old and 18-year-old boys respectively. Results above these thresholds indicate a corpulent figure (Drozdowski, 1998).

Questionnaire data were used to classify the intensity of physical activity according to the following categories: sedentary (no physical activity); minimally active (exercise once a week); active (exercise twice a week); and highly active lifestyle (exercise $3 \geq$ times a week). A unit of physical activity was taken to amount to 45 minutes of physical activity (e.g. swimming, jogging, dancing, pilates, walking, cycling, etc.), engaged in consciously in pursuit of health benefits and leisure. As an additional question, the respondents were asked to declare the duration (number of months) of the given activity.

Moreover, each respondent was asked whether they were guided by health benefits in their choice of food. Each respondent described their body satisfaction level according to the following categories: yes; rather yes; no.

Information about the students' date of birth was used to determine their calendar age on the day of the examination. Calendar age was measured according to the following procedure: age in years and decimal parts of the year (Łaska-Mierzejewska, 1997).

The students included in this anthropological research were examined on three occasions, that is in the three consecutive years of the research project. Most students $(n=25)$ were examined three times and their data lend themselves to a detailed analysis of changes in anthropometrics and survey responses over the course of three years. Other students $(n=4)$ were examined twice, due to their absence at school on the examination day. Arithmetic mean values of anthropometric measurements also include the measurements of students who were only examined once $(n=5)$. These students were only present at school on one of the three examination days.

The analyses for significant relationships between measurements and survey responses from the three years of study took into account only $n=21$ young women, seen as only this number of female students participated in the study in three consecutive years. The research material collected among young men was too small to merit statistical analysis. The analysis was performed using Statistica 12 (StatSoft, Poland). Body measurements and somatic indices were subject to analysis to calculate the arithmetic mean (x), standard deviation (SD), and range (min-max), and the obtained indices were compared to pre-determined categories (standards). Calculations were performed separately for each year of study. To compare the arithmetic means of the measurements, indices and survey data collected according to the year of study, the Kruskal-Wallis test was used, one-way ANOVA by ranks, the non-parametric equivalent of one-way analysis of variance. A non-parametric test was used because some of the measurable variables failed to follow a normal distribution and due to categorisation of somatic indices and survey data. Post-hoc tests (multiple comparison procedures) were performed in all cases. To examine the associations of measurable features and dichotomous data, Pearson and Spearman correlation analysis was performed respectively. 


\section{Results}

The anthropometric measurements and survey data from the three-year study of high-school students were used to calculate the results for each year of study.

Table 1. Arithmetic means of body measurements and somatic indices in female participants over the course of the 3-year study

\begin{tabular}{|c|c|c|c|c|c|c|c|c|c|}
\hline \multirow[t]{2}{*}{ Measure/index } & \multicolumn{3}{|c|}{$\begin{array}{c}2014 \\
(1 \text { st grade, } n=23)\end{array}$} & \multicolumn{3}{|c|}{$\begin{array}{c}2015 \\
(2 \mathrm{nd} \text { grade, } \mathrm{n}=24)\end{array}$} & \multicolumn{3}{|c|}{$\begin{array}{c}2016 \\
(3 r d \text { grade, } n=23)\end{array}$} \\
\hline & $\mathrm{x}$ & $\mathrm{SD}$ & $\min -\max$ & $\mathrm{x}$ & $\mathrm{SD}$ & $\min -\max$ & $\mathrm{x}$ & $\mathrm{SD}$ & $\min -\max$ \\
\hline Calendar age & 16.3 & 0.47 & $15.8-18.1$ & 17.4 & 0.53 & $16.8-19.1$ & 18.3 & 0.54 & $17.8-20.4$ \\
\hline Body height & 166.2 & 6.49 & $154.7-180.4$ & 165.7 & 5.74 & $154.5-178.4$ & 165.9 & 5.94 & $155.0-178.1$ \\
\hline Waist circumference & 76.2 & 9.33 & $63.0-93.0$ & 76.0 & 12.1 & $63.5-106.0$ & 76.3 & 11.21 & $63.0-100.0$ \\
\hline Hip circumference & 99.2 & 9.68 & $86.0-119.0$ & 98.2 & 10.63 & $86.0-122.0$ & 100.0 & 10.92 & $88.0-127.0$ \\
\hline Body weight & 62.7 & 13.57 & $46.0-93.0$ & 61.2 & 14.26 & $47.8-102.0$ & 62.6 & 14.94 & $47.6-102.0$ \\
\hline BMI & 22.5 & 3.74 & $16.8-30.3$ & 22.2 & 4.24 & $16.7-33.2$ & 22.6 & 4.40 & $16.9-33.4$ \\
\hline WHR & 0.8 & 0.05 & $0.7-0.9$ & 0.8 & 0.06 & $0.7-0.9$ & 0.8 & 0.05 & $0.7-0.9$ \\
\hline Rohrer's & 1.4 & 0.20 & $1.0-1.7$ & 1.3 & 0.24 & $1.0-1.9$ & 1.4 & 0.24 & $1.0-1.9$ \\
\hline
\end{tabular}

Table 2. Arithmetic means of body measurements and somatic indices in male participants over the course of the 3-year study

\begin{tabular}{|l|c|c|c|c|c|c|c|c|c|}
\hline \multirow{2}{*}{ Measure/index } & \multicolumn{3}{|c|}{$\begin{array}{c}2014 \\
\text { (1st grade, } \mathrm{n}=7)\end{array}$} & \multicolumn{3}{c|}{$\begin{array}{c}2015 \\
\text { (2nd grade, } \mathrm{n}=4)\end{array}$} & \multicolumn{3}{c|}{$\begin{array}{c}2016 \\
\text { (3rd grade, } \mathrm{n}=6)\end{array}$} \\
\cline { 2 - 11 } & $\mathrm{x}$ & $\mathrm{SD}$ & $\min -\max$ & $\mathrm{x}$ & $\mathrm{SD}$ & $\mathrm{min}-\mathrm{max}$ & $\mathrm{x}$ & \multicolumn{1}{c|}{ SD } & min-max \\
\hline Calendar age & 16.32 & 0.29 & $15.97-16.69$ & 17.25 & 0.36 & $16.90-17.60$ & 18.43 & 0.310 & $17.96-18.71$ \\
\hline Body height & 179.57 & 7.38 & $171.5-191.1$ & 178.85 & 8.21 & $172.4-190.7$ & 180.77 & 7.570 & $173.00-178.20$ \\
\hline Waist circumference & 80.71 & 7.85 & $69.0-93.0$ & 83.25 & 5.25 & $76.00-88.00$ & 84.50 & 4.950 & $77.00-90.00$ \\
\hline Hip circumference & 99.0 & 8.64 & $90.0-112.0$ & 100.50 & 7.05 & $92.00-109.00$ & 99.50 & 4.230 & $93.00-106,00$ \\
\hline Body weight & 72.71 & 8.46 & $60.0-85.0$ & 76.78 & 9.84 & $63.10-86.2$ & 76.82 & 6.720 & $64.80-84.10$ \\
\hline BMI & 22.58 & 2.60 & $19.17-25.66$ & 23.95 & 1.99 & $21.23-25.50$ & 23.49 & 1.210 & $21.65-24.82$ \\
\hline WHR & 0.80 & 0.03 & $0.77-0.84$ & 0.83 & 0.02 & $0.81-0.84$ & 0.85 & 0.001 & $0.81-0.89$ \\
\hline Rohrer's & 1.26 & 0.17 & $1.00-1.44$ & 1.34 & 0.12 & $1.23-1.45$ & 1.30 & 0.090 & $1.19-1.40$ \\
\hline
\end{tabular}

Comparative analysis of arithmetic means of the measurements and somatic indices demonstrated that the differences in the results of female students in 1st, 2nd and 3rd grade were not statistically significant. This finding suggests that questionnaire responses and body measurements did not differ sufficiently for it to be borne out by significance calculations. It needs to be emphasised that only $n=21$ girls were included in significance calculations, i.e. only those respondents who were examined three times. 


\section{Women's somatic indices}

Table 3. Results of young women's somatic indices with categorisation

\begin{tabular}{|c|c|c|c|c|c|c|c|}
\hline \multirow[t]{2}{*}{ Index } & \multirow[t]{2}{*}{ Category } & \multicolumn{2}{|c|}{$\begin{array}{c}2014 \\
(1 \text { st grade, } n=23)\end{array}$} & \multicolumn{2}{|c|}{$\begin{array}{c}2015 \\
(\text { 2nd grade, } \mathrm{n}=24)\end{array}$} & \multicolumn{2}{|c|}{$\begin{array}{c}2016 \\
(3 \mathrm{rd} \text { grade, } \mathrm{n}=23)\end{array}$} \\
\hline & & $\mathrm{n}$ & $\%$ & $\mathrm{n}$ & $\%$ & $\mathrm{n}$ & $\%$ \\
\hline \multirow{3}{*}{ BMI } & underweight & 2 & 9 & 2 & 8 & 2 & 9 \\
\hline & normal & 17 & 74 & 18 & 75 & 17 & 74 \\
\hline & excess kilograms & 4 & 17 & 4 & 17 & 4 & 17 \\
\hline \multirow{2}{*}{ WHR } & gynoid type & 15 & 65 & 18 & 75 & 18 & 78 \\
\hline & android type & 8 & 35 & 6 & 25 & 5 & 22 \\
\hline \multirow{2}{*}{ Rohrer's } & lean figure & 14 & 61 & 16 & 67 & 15 & 65 \\
\hline & corpulent figure & 9 & 39 & 8 & 33 & 8 & 35 \\
\hline
\end{tabular}

\section{Men's somatic indices}

Table 4. Results of young men's somatic indices with categorisation

\begin{tabular}{|c|c|c|c|c|c|c|c|}
\hline \multirow[t]{2}{*}{ Index } & \multirow[t]{2}{*}{ Category } & \multicolumn{2}{|c|}{$\begin{array}{c}2014 \\
(1 \text { st grade, } \mathrm{n}=7)\end{array}$} & \multicolumn{2}{|c|}{$\begin{array}{c}2015 \\
(\text { 2nd grade, } n=4)\end{array}$} & \multicolumn{2}{|c|}{$\begin{array}{c}2016 \\
(3 r d \text { grade, } n=6)\end{array}$} \\
\hline & & $\mathrm{n}$ & $\%$ & $\mathrm{n}$ & $\%$ & $\mathrm{n}$ & $\%$ \\
\hline \multirow{3}{*}{ BMI } & underweight & 0 & 0 & 0 & 0 & 0 & 0 \\
\hline & normal & 5 & 71 & 2 & 50 & 6 & 100 \\
\hline & excess kilograms & 2 & 29 & 2 & 50 & 0 & 0 \\
\hline \multirow{2}{*}{ WHR } & gynoid type & 2 & 29 & 0 & 0 & 0 & 0 \\
\hline & android type & 5 & 71 & 4 & 100 & 6 & 100 \\
\hline \multirow{2}{*}{ Rohrer's } & lean figure & 4 & 57 & 2 & 50 & 3 & 50 \\
\hline & corpulent figure & 3 & 43 & 2 & 50 & 3 & 50 \\
\hline
\end{tabular}

The activity levels for young women over the course of the three years of study were relatively stable. In first grade, $83 \%$ of girls were active or highly active, while $17 \%$ were minimally active. Moreover, as many as $65 \%$ of all young women engaged in additional sports activities in their free time. First grade was characterised by more physical activity than school years two and three among women. In second grade, active and highly active women accounted for $58 \%$, and minimally active women for $42 \%$, whereas in third grade these figures were $56 \%$ and $44 \%$ respectively, with additional sports activity pursued by $61 \%$ of the female respondents. The intensity of physical exercise declined year by year.

A similar percentage distribution was observed in women's responses to the question about their body satisfaction. The highest degree of dissatisfaction was visible in first grade $(56 \%$ dissatisfied), going hand in hand with the highest degree of physical activity (83\%). One of the explanations may be that the girls exercised because they wanted to lose weight. In second and third grade of high school, female students tended to be happier about their bodies (54\%), even 
though a decline in physical activity was observed in the last two years of school. This may reflect a growing acceptance of own body among the studied women. This finding goes against the grain of many other studies on this subject, where girls with age get increasingly dissatisfied and undertake more measures to improve the appearance of their bodies, often resorting to drastic methods, such as for instance using restrictive and unhealthy diets and engaging in excessively strenuous exercise.

The level of physical activity among the studied men was more satisfactory. In first grade, $100 \%$ of men were active or highly active, in second grade this number dropped to $75 \%$, and a sedentary lifestyle was declared by $25 \%$. In turn, in third grade active and highly active men accounted for $80 \%$ and minimally active men for $20 \%$, which means that the studied young men were physically active. All third-grade students declared that they engaged in additional sports other than physical education classes at school.

The percentage distribution of body satisfaction among men shows that in first grade $71 \%$ were dissatisfied, $29 \%$ were rather satisfied, and there was no-one fully satisfied with his body. Second grade brought about a significant change, because those fully and partly satisfied accounted for $75 \%$ in total, and only $25 \%$ were dissatisfied (a drop from 71 to $25 \%$ ), whereas in third grade the level of dissatisfaction went up again to $50 \%$.

These results show that young men were more critical of their bodies than women, especially so in first and third grade, with the following dissatisfaction trend in girls: $56 \% \rightarrow 46 \% \rightarrow 46 \%$, and in boys: $71 \% \rightarrow 25 \% \rightarrow 50 \%$.

BMI scores show that a strong majority of the class included in the study, both sexes, fell in the normal range. Among women, in the course of the three years $74-75 \%$ of the group fell in the normal range, $8-9 \%$ were underweight, and 17\% had excess kilograms. According to Rohrer's index, $61-67 \%$ of the girls had lean figures in the space of three years. These numbers show that the young women were too critical in their body self-assessment. On the other hand, WHR results for women show that such strong body dissatisfaction among female students may have been caused by the pattern of body fat distribution, as well as too much or too little body fat. The android type (the apple shape - typical of men) was found in $22-35 \%$ of the young women in the space of three years. The android type in women may be caused by too much visceral fat or too narrow hips and means that the female figure loses its characteristic hour glass shape.

Among the young men, no-one was underweight, but two individuals in first grade represented the gynoid type of fat distribution (the pear shape - characteristic for women). These results may suggest that body satisfaction among men goes up together with body weight (particularly muscle mass) and in correlation with body shape, which is a reflection of today's male body trends.

\section{Discussion}

The analysis of the above results reveals little change in terms of body height for both young men and women involved. Body weight, waist circumference and hip circumference also remain almost unchanged in women. In young men, however, these three parameters paint a different picture, whereby over the course of three years significant changes can be seen, in terms of both body weight, which gradually went up by an average of about $4 \mathrm{~kg}$, and waist circumference, which went up by about $4 \mathrm{~cm}$ on average, with negligible fluctuations in hip circumference.

The small differences in body build of the students included in the study are probably due to the fact that high-school age coincides with the final stage of puberty, when growth rate is not as spectacular as the growth spurts in middle school. Greater differences in body measurements 
and weight among the studied young men may on the one hand be attributed to the later onset of puberty, which continues in men up to more or less 20 years of age, where in women it is over by the age of approx. 18. On the other hand, faster and greater growth of muscle mass is natural for men at this age. Another factor at play may be that the young men in this study were involved in much more physical activity than women, which translates into muscle growth, and consequently weight gain. It is a common practice among young men to put on weight deliberately, so as to sculpt a muscular physique later. Nearly all men included in the study declared high physical activity, which is related to a keen interest in sports, including working out at the gym, team games and martial arts, among men. Some studies show that more and more women are interested in "sculpting" their bodies, but this aspiration is much more common for men (McCreary, Saucier, 2009).

Physical activity is a very important factor facilitating weight loss, whose effects are more durable if the individual (particularly an overweight person) is more disciplined about keeping up regular physical exercise. The type of physical activity chosen may be very different and, like with the choice of diet, there is no one right way that will achieve the same therapeutic effect in everyone. Besides, any form of activity has a profound impact on improving psychosomatic well-being (Romanowska-Tołłoczko, Kałwa, 2014).

Weight loss should not exceed $0.5 \mathrm{~kg}$ per week, and the optimal rate of weight loss is $0.25 \mathrm{~kg}$ per week, seen as at this pace it will not slow down metabolism (Levitsky, 2005). Rapid weight loss is conducive to (just as rapid) weight gain after coming off the diet, and the pace of both these processes is proportionate (McGuire, 1999).

To sum up, while studies show that women generally want to reduce their body weight (Lipowska, Lipowski, 2006), two trends can be identified with regard to men: one is to get rid of surplus kilograms, but the other, much more common, is to increase muscle mass - which inevitably leads to an increase in overall body weight (Tylka, 2011).

In recent years, there has been a growing number of empirical reports indicating that more and more men are dissatisfied with many different aspects of their bodies (Frederick et al., 2007). Studies on the attractiveness of male body to the opposite sex show that men tend to overestimate the role of a muscular physique as an important determinant in the choice of a partner (Diedrichs, Lee, 2010). Own research shows clearly that when students engaged in additional sports activity, their body satisfaction increased.

However, body measurements and weight may not be treated as the only determinants of men's increasing dissatisfaction. Men attach equal importance to physical fitness, which is a guarantee of self-confidence and attractiveness to the opposite sex (Lipowski, Lipowska, 2015).

The very small number men in the study group generally prohibits far-reaching conclusions from statistical analysis. The class included in the study was predominantly female.

Studies show that the most common nutritional errors among teenagers are related to the insufficient intake of fruit and vegetables in everyday diet, coupled with excessive consumption of fats and sweets. The favourite food products named by young people include calorie-rich fast-food type meals (Wojtyła-Buciora, Marcinkowski, 2010).

When it comes to the choice of food for its health benefits, women fare better than men, but their results are far from satisfactory. In first grade $52 \%$ of young women declared they take note of what they eat. Otherwise, $22 \%$ of female students said they do it sometimes, and $26 \%$ did not pay attention to the health properties of the food they eat, so in other words their food choices were not health-oriented. The second year at high school was different, with the following respective percentage distribution: $46 \%$ (yes), $46 \%$ (sometimes) and $8 \%$ (do not pay attention to the choice of 
food). There was a noticeable drop in second grade in the number of girls who paid no attention whatsoever $(26 \% \rightarrow 8 \%)$, and an increase among those who sometimes paid attention to food choices $(22 \% \rightarrow 46 \%)$. In third grade the picture gets brighter because the choice of healthy food was always an issue for $52 \%$ of female respondents, sometimes - for $44 \%$, and only $4 \%$ ignored the health properties of what they ate. This may be a sign of a growing awareness among the young women as to the positive impact of nutrition on one's body and appearance, pointing to the students' growing knowledge about the disastrous effects of junk food.

Among the studied men, the majority unfortunately did not attach much weight to what they eat. In first grade, $43 \%$ of the studied young men responded that they do not pay attention to the health benefits of food, the same percentage said they sometimes paid attention, and only $14 \%$ chose their meals consciously. Responses in second grade were more varied, with $50 \%$ of male respondents declaring they do not pay attention to the quality of food, $25 \%$ that they take note sometimes, and $25 \%$ that they chose their meals consciously. Third grade revealed the greatest diversity in survey responses because as many as $67 \%$ of respondents did not pay attention to the choice of food products, but on the other hand, the greatest percentage of all three years, 33\%, declared that they chose food products according to their health properties.

In the final year at high school a clear division becomes visible between conscious eaters and those who do not pay attention to the nutritional value of their meals. This may be a token of the growing knowledge about healthy nutrition in the Polish society. It may be assumed that awareness of healthy eating, nutritional value of food products and the role of physical activity for shaping a healthy body will continue to grow. It is encouraged by the growing trend for "being fit", which is increasingly promoted in social media and on television, by celebrities, presenters as well as professional trainers and chefs.

\section{Conclusions}

The analysis of results has led to the following final conclusions:

1. Only half of young women made their food choices based on health benefits. The young men included in the analysis were less likely to pay attention to healthy food choices.

2. The strong body criticism among first-grade female students may be explained by the fact that finding themselves in a new peer group made them conscious of the shortcomings in their bodies and awoke aspirations for a slimmer figure.

3. The differences in survey responses and body measurements in the young women included in the analysis over the course of three years of observation did not have statistical significance. It means that changes in body measurements and responses provided by female students in the questionnaire were rather small.

4. A lower degree of body satisfaction among the young men corresponded to an increased interest in additional sports activity.

5. The interest in physical activity among the young women was relatively stable over the three years of study, peaking in first grade. Among the young men physical activity remained high throughout high school, and was especially so in first and third grade.

6. In the space of three years of high school, as many as four girls and two boys (in the first two years of study) had dangerously elevated BMI scores. Excess weight at such an early stage of adulthood may lead to the development of metabolic disorders and result in diseases of civilisation.

7. Satisfaction levels in young men increased together with body weight. 
8. There is a visible need for the development of programmes promoting body awareness and self-acceptance among school youth.

\section{Acknowledgments}

We wish to extend our warmest thanks to the Principal of High School no 7 in Szczecin for allowing us to conduct anthropological research at the school. We also want to thank the students who agreed to participate in the study and the Form Teacher for her commitment and assistance in organising the measurements.

\section{References}

Diedrichs, P.C., Lee, Ch. (2010). GI Joe Or Average Joe? The impact of average-size and muscular male fashion models on men's and women's body image and advertisement effectiveness. Body Image, 3 (7), 218-226. DOI: 10.1016/j.body-im.2010.03.004.

Drozdowski, Z. (1998). Antropometria w wychowaniu fizycznym. Poznań: AWF.

Frederick, D.A., Buchanan, G.M., Sadehgi-Azar, L., Peplau, L.A., Haselton, M.G., Berezovskaya, A. Lipinski, R.E. (2007). Desiring the muscular ideal: Men's body satisfaction in the United States, Ukraine and Ghana. Psychology of Men \& Masculinity, 8, 103-117. DOI: 10.1037/1524-9220.8.2.103.

Kakeshita, I.S., Almeida, S.S. (2006). Relationship betwen body mass index and self-perception among university students. Rev Saúde Pública, 3 (40).

Levitsky, D.A. (2005). The non-regulation of food intake in humans: hope for reversing the epidemic of obesity. Physiol Behav, 5 (86), 623-632.

Lipowska, M., Lipowski, M. (2006). Ocena własnej atrakcyjności przez kobiety w różnym wieku. In: A. Chybicka, M. Kaźmierczak (eds.), Kobieta w kulturze - kultura w kobiecie (pp. 385-402). Kraków: Oficyna Wydawnicza Impuls.

Lipowski, M., Lipowska, M. (2015). Poziom narcyzmu jako moderator relacji pomiędzy obiektywnymi wymiarami ciała a stosunkiem do własnej cielesności młodych mężczyzn. Polskie Forum Psychologiczne, 1 (20), 31-46.

Łaska-Mierzejewska, T. (1997). Ćwiczenia z antropologii. Warszawa: AWF.

McCreary, D.R., Saucier, D.M. (2009). Drive for muscularity, body comparison and social physique anxiety in men and women. Body Image, 1 (6),24-30.

McGuire, M.T. (1999). What predicts weight regain in a group of successful weight losers? J Consult Clin Psychol, 67, 177-185.

Myszkowska-Ryciak, J., Gago, E., Harton, A. (2015). Wiedza żywieniowa oraz postrzeganie własnej masy ciała przez nastoletnie dziewczęta. In: A. Wolska-Adamczyk (ed.), Znaczenie racjonalnego żywienia w edukacji zdrowotnej. Warszawa: WSIiZ.

Patton, G.C., Selzer, R., Coffey, C., Carlin, J.B., Wolfe, R. (1999). Onset of adolescent eating disorders: population based cohort study over 3 years. Br. Med. J., 318 (7186), 765-768.

Physical status: the Use and Interpretation of Anthropometry (1995). Report of a WHO expert committee. WHO Tech Rep Ser, 854, 1-452.

Romanowska-Tołłoczko, A., Kałwa, M. (2014). Oddziaływania psychologiczne w kompleksowej terapii nadwagi. Probl Hig Epidemiol, 2 (95), 209-214.

Sandler, R., Slemenda, C.W., LaPorte, R.E., et al. (1985). Postmenopausal bone density and milk consumption in childhood and adolescence. Am J Clin Nutr, 42, 270-274. 
Schneider, N., Frieler, K., Pfeiffer, E., Lehmkuhl, U., Salbach-Andrae, H. (2009). Comparison of body size estimation with different types of eating disorders. Eat Disord Rev, 17, 468-475.

Sorensen, T., Stunkard, A., Teasdale, T., Higgins, M. (1983). The accuracy of reports of weight: children's recall of their parents weights 15 y earlier. Int $J$ Obs, 7, 115-122.

Szponar, L., Respondek, W. (2000). Choroby pierwotne na tle niedoborów żywieniowych. Żywienie człowieka zdrowego i chorego. Warszawa: Wydawnictwo Naukowe PWN.

Tanofsky-Kraff, M., Cohen, M.L., Yanovsky, S.Z., Cox, Ch., Heim, K.R., Keil, M., Reynolds, J.C., Yanovski, A. (2006). A prospective study of psychological predictors of body fat gain among children at high risk for adult obesity. Pediatrics, 117, 1203-1209.

The Surgeon General's Report on Nutrition and Health (1988). Washington, DC: US Public Health Service, Office of the Surgeon General.

Tylka, T.L. (2011). Refinement of the tripartite influence model for men: Dual body image pathways to body change behaviors. Body Image, 3 (8), 199-207.

Wojtyła-Buciora, P., Marcinkowski, J.T. (2010). Sposób żywienia, zadowolenie z własnego wyglądu i wyobrażenie o idealnej sylwetce młodzieży licealnej. Probl Hig Epidemiol, 2 (91), 227-232.

Woynarowska, B. (2003). Środowisko psychospołeczne szkoły i przystosowanie szkolne a zdrowie i zachowanie zdrowotne uczniów w Polsce. Raport z badań. Warszawa.

Cite as: Rębacz-Maron, E., Lisiecki, P. (2017). Body satisfaction versus anthropometric and lifestyle characteristics in secondary school youth in a three-year study. Acta Biologica, 24, 89-99. DOI: 10.18276/ ab.2017.24-09. 